
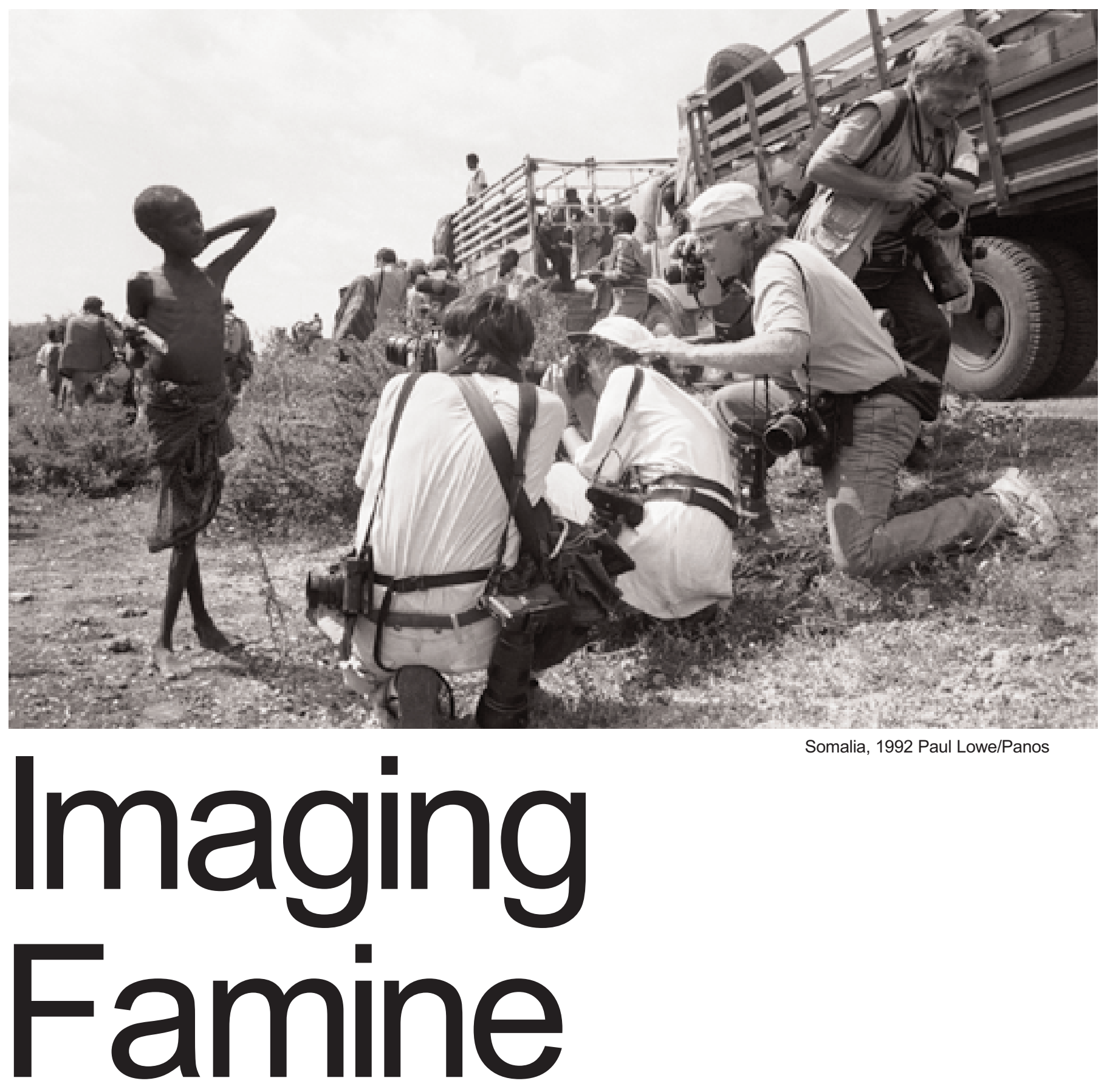

Somalia, 1992 Paul Lowe/Panos

\title{
The Guardian
}




\section{Imaging Famine}

Band Aid 20. Live 8. Make Poverty History. The G8 Summit in Gleneagles. 2005 is witnessing renewed debate about global poverty, disasters and development, especially in Africa. Coming two decades after the Ethiopian famine of the mid1980s the time is ripe for a reconsideration of the power and purpose of disaster pictures, given the way the images of the Ethiopian famine spawned the original Band Aid/Live Aid phenomenon.

The October 1984 BBC television report from Korem (filmed by Mohamed Amin and reported by Michael Buerk) is renowned for having drawn the world's attention to the famine in Ethiopia. While it was not the first report of the issue, it is undoubtedly the most famous. Its eight minutes of searing images moved news professionals and the public alike. This response was not universal - "not more starving Africans", was the reaction of one network producer. However, another producer identified what gave the report its power, saying, "it was as if each clip was an award-winning still photo". As a result, some 425 television stations around the world ran the report, reaching hundreds of millions of people.

The media coverage of the Ethiopian famine was a watershed for how aid agencies thought about images of disaster. The Food and Agriculture Organisation of the United Nations undertook an international study of the campaigns and coverage (called Images of Africa) to see their effects on the European public's perception of Africa. Out of this came new codes of practice for the use of pictures by non-governmental organisations (NGOs). Since then, reflections on the politics of photographic practice with regard to famine have been scant and the persistence of stereotypical images all too evident. As a result, part of the Live Aid legacy has been the equation of famine with Africa and Africa with famine, reducing a continent of 57 countries, nearly 900 million people and numerous disparate cultures to a single, impoverished place.

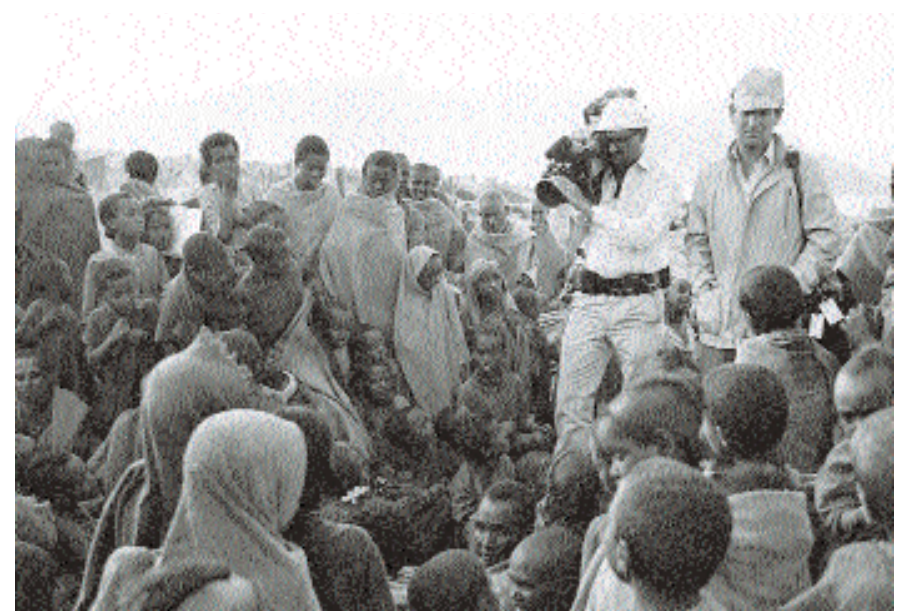

Mohamed Amin and Michael Buerk, Ethiopia, 1984 Camerapix 
The purpose of Imaging Famine is to reignite debate about these issues. To achieve this, the exhibition has six components:

- 20 boards detailing themes that have affected famine coverage in recent decades;

- two photo essays from Sudan in 1998 by Paul Lowe and Tom Stoddart that contrast the work of photojournalists with the news images on the boards;

- images from 19th and early 20th century famines to provide historical context;

- a gallery of alternative images;

- interactive screens with interviews where academics, photographers, picture editors and aid agency officials offer contrasting views on the main themes;

- a website with supplementary information www.imaging-famine.org

The exhibition and this catalogue do not claim to have addressed all the relevant issues, nor do they answer definitively the specific questions posed on the thematic boards. Neither do they present a manifesto on the correct use of images in the media. Instead, they aim to draw public attention to issues that should animate debate among the producers and consumers of disaster imagery and to encourage further reflection by all concerned. This catalogue discusses some of the enduring concerns to give a flavour of the main parameters of the debate.

Imaging Famine is an ongoing, web-based project and feedback is encouraged. Please go to the website for contact details on how to submit comments www.imaging-famine.org

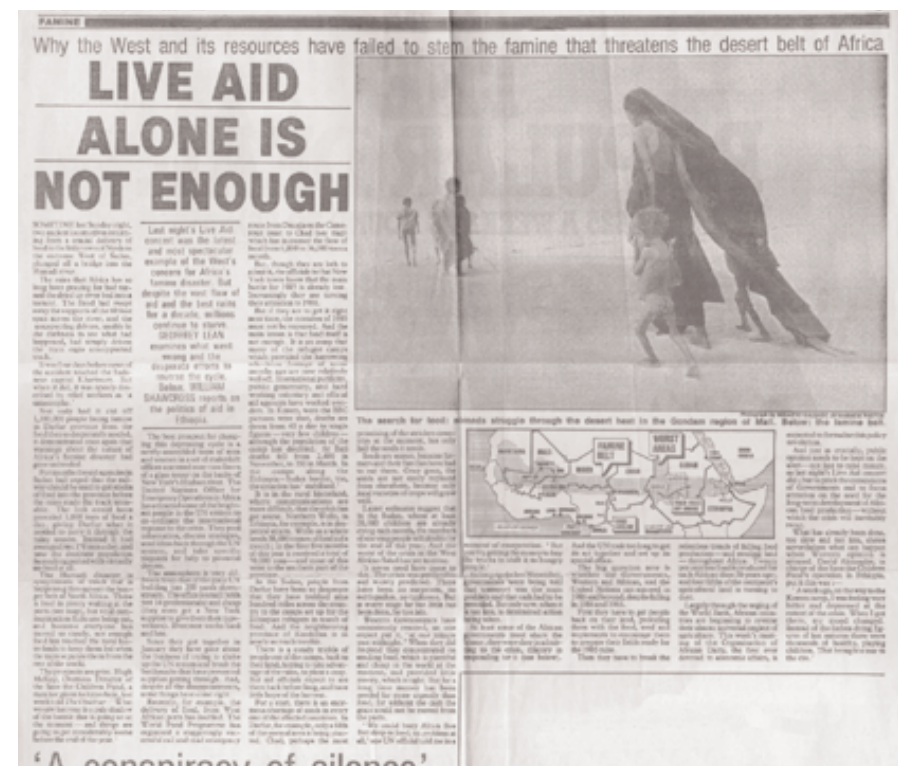

The Observer, July 141985 Photographer: Sebastiao 


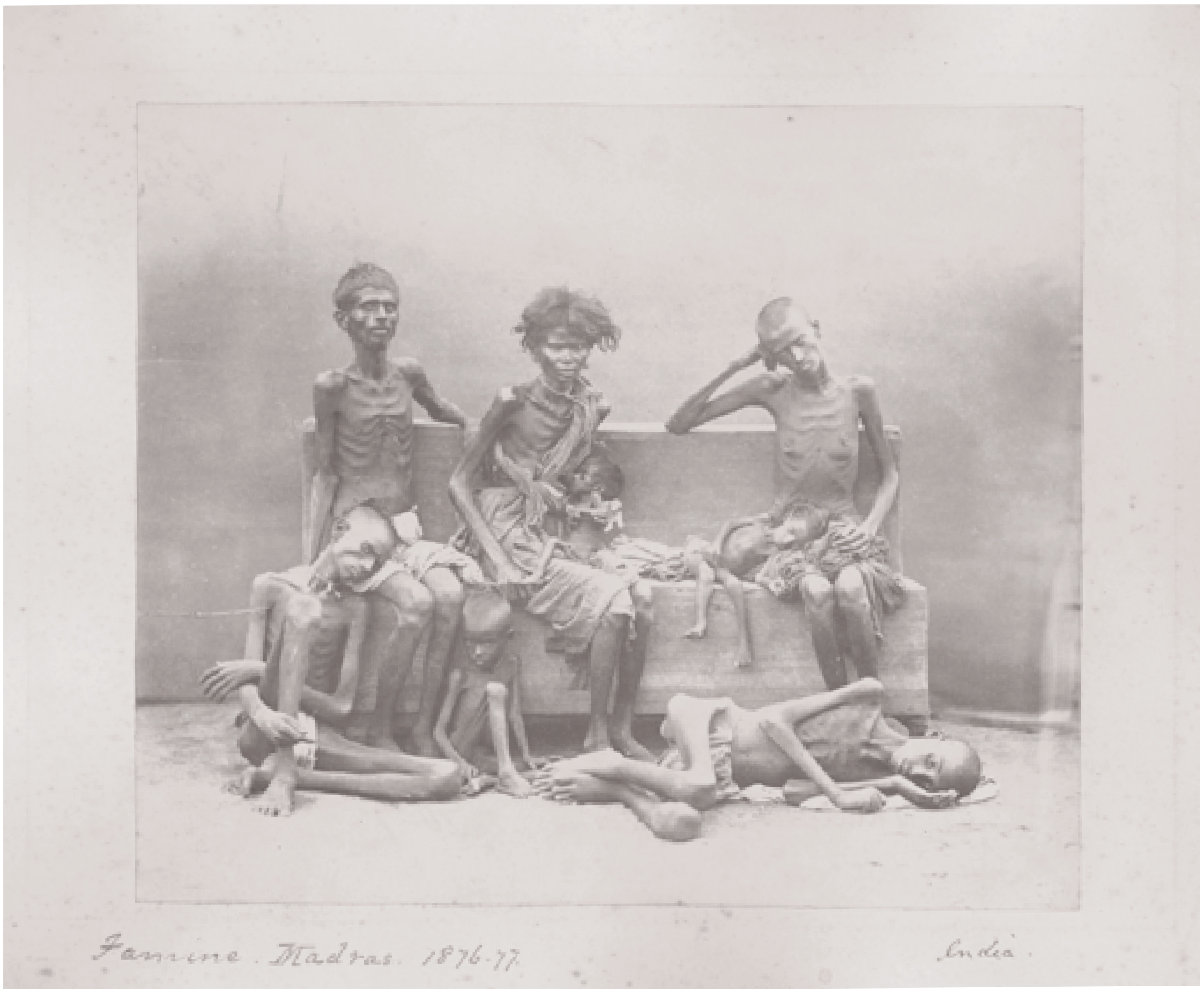




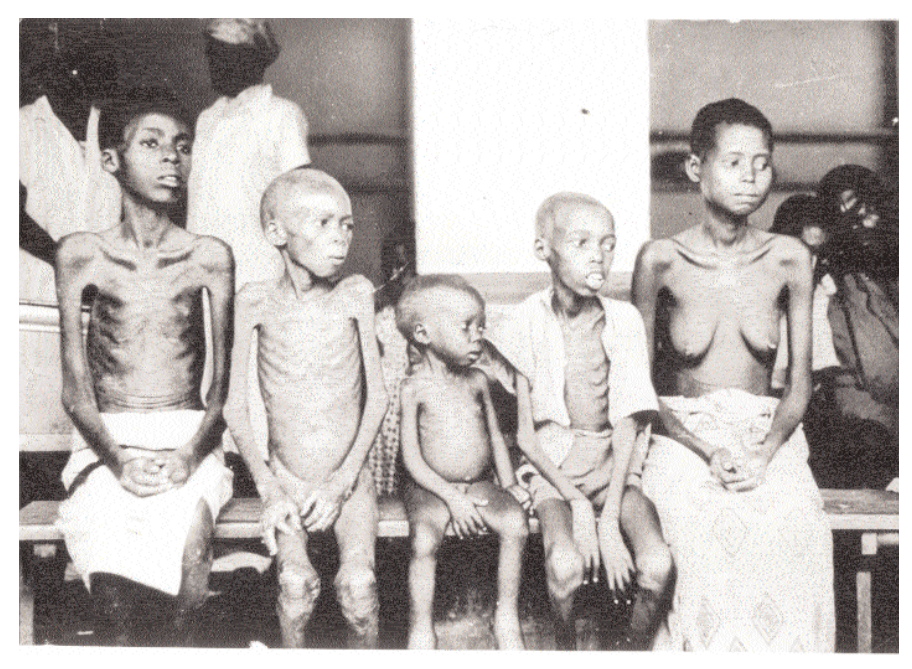

\section{Congo, unknown photographer, 1961}

Oxfam no longer uses images such as this; since the mid-1980s its policy has been to represent people fairly and with respect for their dignity. However, it was used extensively in 1961 as part of an ad campaign which is, in part, credited with establishing Oxfam as a household name. Interestingly, the photograph was cropped in the ad - the bare breasted woman to the right was removed, presumably for reasons of "decency". The photograph, like the image from Madras in 1876-77, has been posed and the two naked children have probably been instructed to cover their genitalia with their hands.

Courtesy of the International Committee of the Red Cross, via Oxfam

Famine victims, Madras, by Captain Hooper, 1876-77

Between 1876 and 1879 , approximately 10 million people died as a result of severe drought and crop failure. This situation was further exacerbated by a world economic depression from 1873, which caused a sharp drop in commodity prices. This is one of the earliest extant photographs of famine victims. Nothing is known of the photographer, Captain Hooper, although his name suggests that he was part of the British military presence in India. The image is striking because it seems that the subjects have been posed indoors - the figure to the right is too malnourished to sit up, and the figure to the left on the floor seems to be supported by a rope. There is an extraordinarily dispassionate quality to the image on the part of the photographer, perhaps explained by the fact that, until relatively recently, famines were seen as natural occurrences, nature's way of righting itself; in other words, the agency of God. 


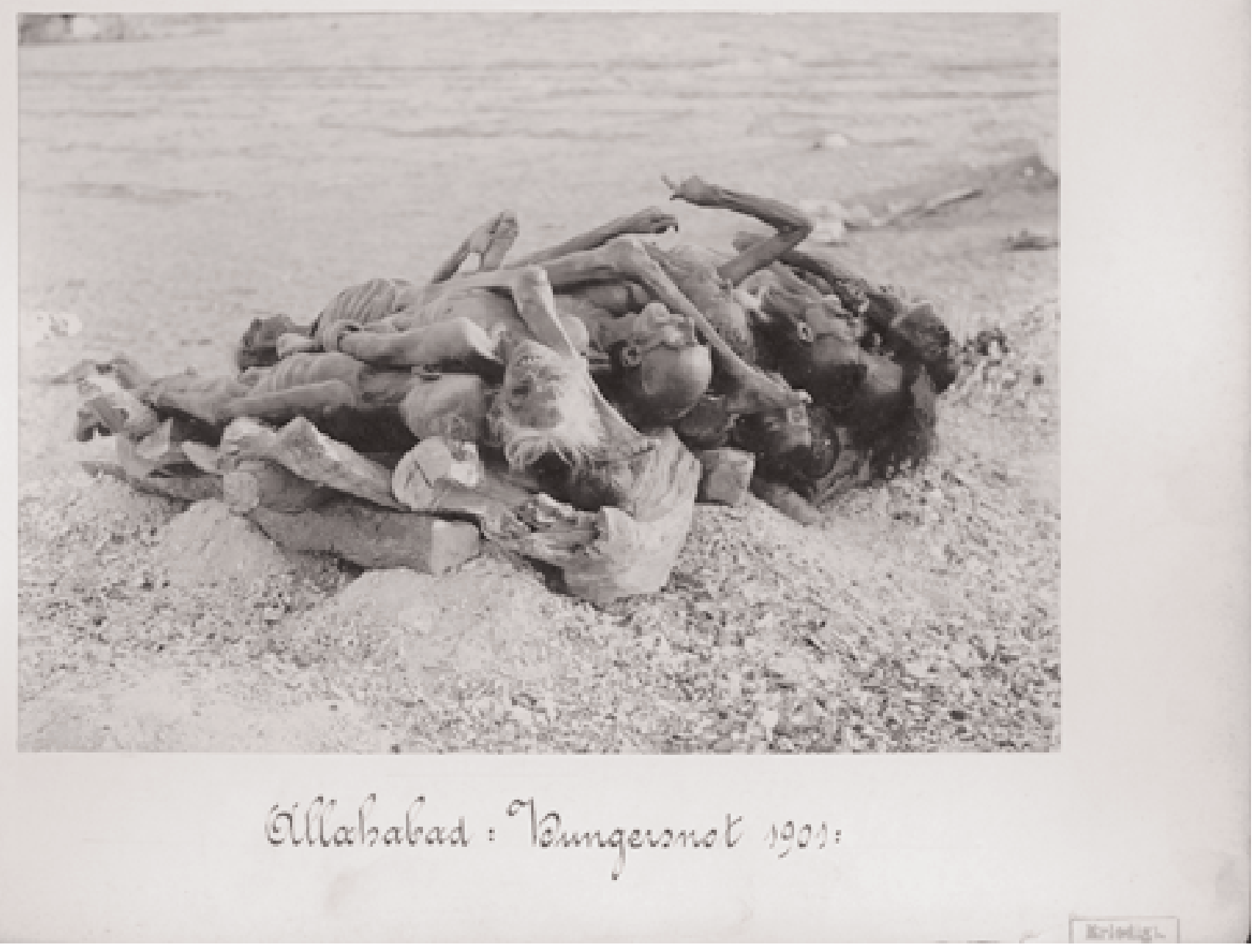




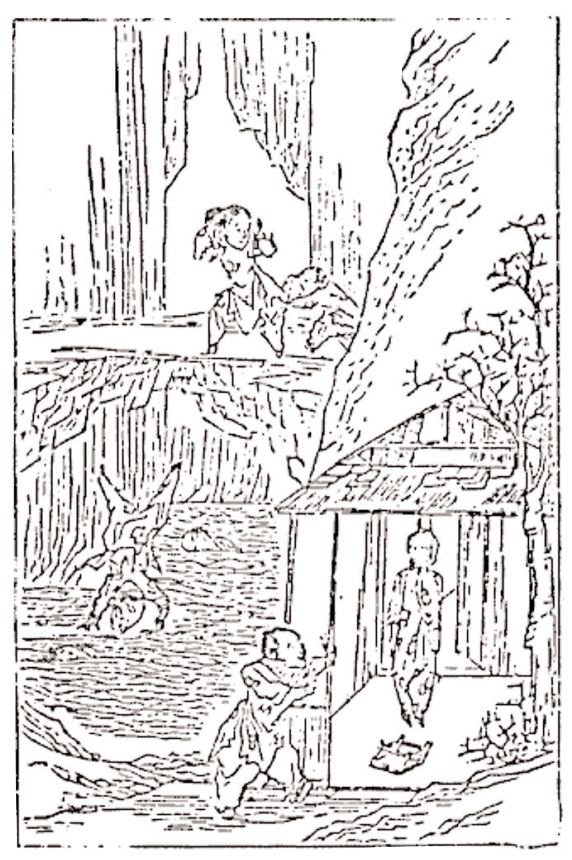

Illustrations of a Chinese Famine, unknown artist, 1878

Between 1876 and 1879, approximately 13 million people died throughout China due to sustained monsoons in the Guangdong and Fujian regions, and drought in much of the north. Environmental conditions were compounded by corrupt administration. These illustrations were published in England in 1878 specifically to raise awareness of the dire situation. The illustrations belie the gruesome subject matter, which shows the stripping of bark and leaves from trees and thatch from houses for food, the selling of children into slavery, and suicide.

The Famine in China, Illustrations by a Native Artist, London: China Famine Relief Fund/Kegan Paul \& Co., 1878

Famine victims, Allahabad, unknown photographer, 1901

Between 1896 and 1902, approximately 19 million perished in India during a period of repeated monsoon failure. Most of the victims perished as a result of diseases such as malaria, bubonic plague, dysentery, smallpox and cholera. These extraordinary photographs of the famine dead, taken by an unknown German photographer, are extremely early examples of images which make no attempt to dilute the horror of what is happening. However, these images predate mass photojournalism by some three decades and were possibly taken by a "tourist" for his or her private consumption. It was not until the Holocaust that extreme images like this gained a wider currency. 


\section{what is the appeal?}

Charity appeals are organised around often stereotypical images of victims. These appeals raise millions of pounds, thereby demonstrating the continuing power of the pictures. But are these short term benefits offset by the long-term effects of reproducing images with cultural and racial stereotypes?

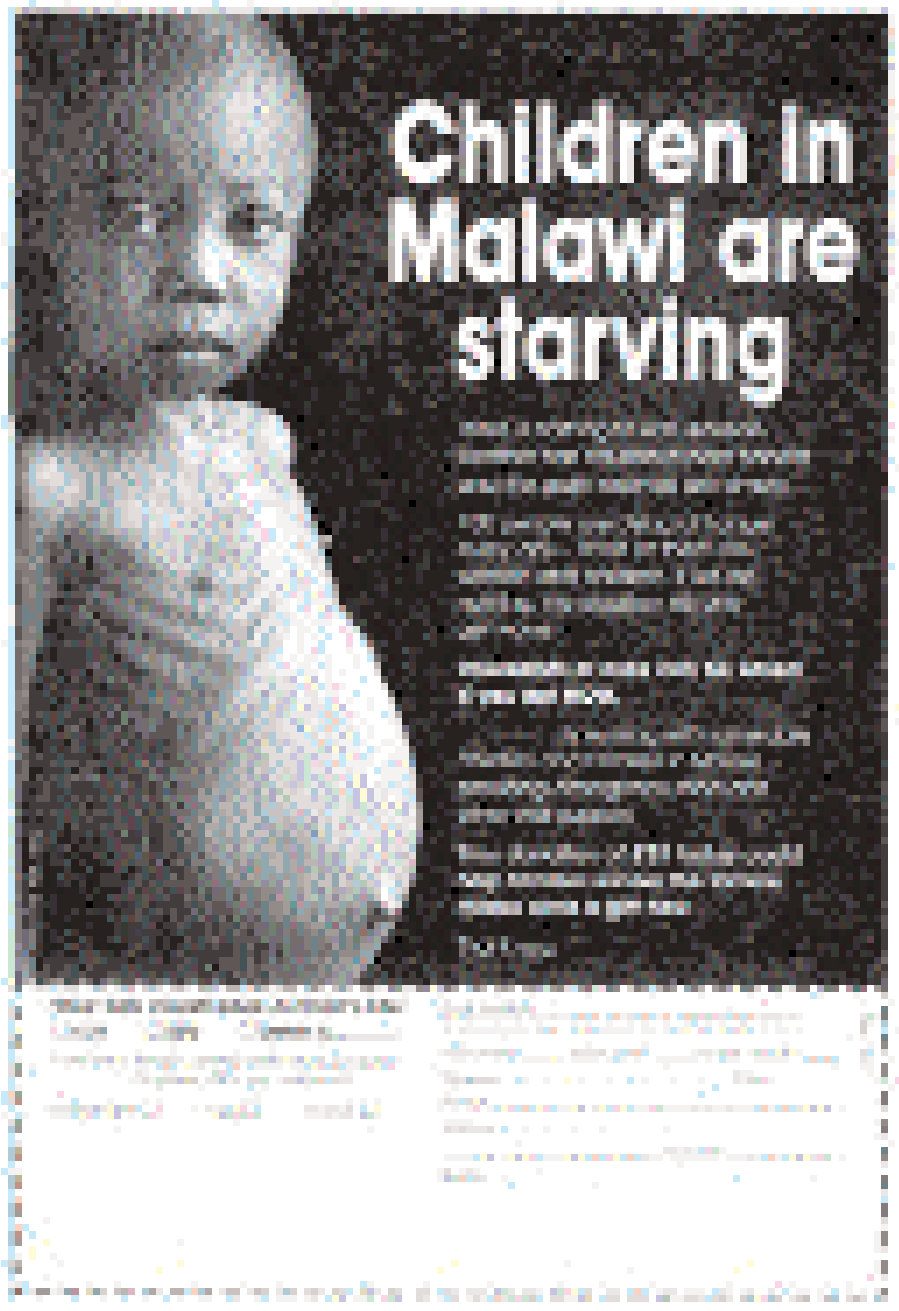

The Guardian, June 192002 Photograph: Daily Mirror, courtesy of Mirror Group Newspapers 


\section{positive versus \\ negative images}

War and famine are newsworthy. Suffering and disaster capture media attention. But are the images associated with such reporting necessarily negative? Is it possible for the media to present positive images of people in need? Would such images be appropriate if they minimised the scale of suffering? Are negative images inherently necessary for fundraising by development NGOs, or do they only breed despair and a sense that nothing can be done about seemingly intractable situations?

One way to answer such questions is to highlight moral imperatives to tell the truth, avoid sensationalism and respect the dignity of human beings (however awful their situations). Such considerations apply to both the news media and development NGOs, even though different producers and consumers of images require different pictures. For the media, the emphasis is on accuracy and immediacy. For aid agencies, one response is to draw a temporal distinction between fundraising as a short-term imperative and education as a longterm aim, or between short-term emergencies and long-term development. Here, positive images may be seen as those that reflect positive stories about long-term projects designed to achieve sustainable development. Another way to emphasise the positive would be to focus on positive outcomes - the way that funds raised for humanitarian assistance have reached their designated targets and saved lives, for example.

An unresolved issue is whether the ends necessarily justify the means. If morally suspect images cause people to act (either by donating money for disaster relief or lobbying for political justice) then should they be avoided at all cost? Is an image necessarily negative if it produces a positive outcome?

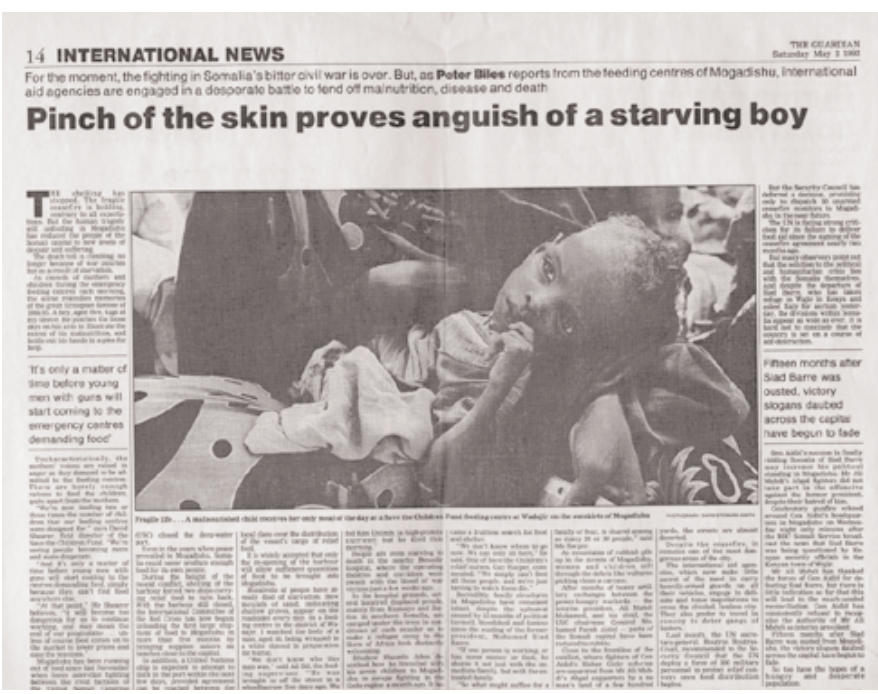

The Guardian, May 21992 Photographer: David Steward- 


\section{the nature of photojournalism}

The impact of a well-chosen photograph is immediate, and a powerful way to get a message across. And yet images can also be greatly changed by the addition of captions and text. Indeed, an image without a caption is arguably purely aesthetic (like a family portrait), short of clear meaning and not photojournalism at all. But what exactly is the purpose of caption and text? Is it simply to say what the picture is about, or is it meant to challenge assumptions, tell a story, convey a message, advertise good work, raise consciousness, raise funds, and rouse emotions?

Complicating those questions is the issue of who is writing captions and text. As the witness, that task is predominantly the photographer's. But photographers are only one link in an increasingly global image production and distribution chain. They may not have free reign to shoot whatever they desire, and they do not control how the images appear in the press, to whom they are sold, and the way they are then captioned, titled or positioned in relation to articles. Photographers' material is edited through various filters by others, including photo agencies and picture editors, who may have conflicting priorities. Another enduring issue is therefore the extent to which photojournalism can appropriately provide images with context, understanding and explanation. This may depend on other factors, such as whether a photographer has the licence to provide multiple images, whether the photographer's subject is a hot topic at the time, and whether it is a quiet news day or not.

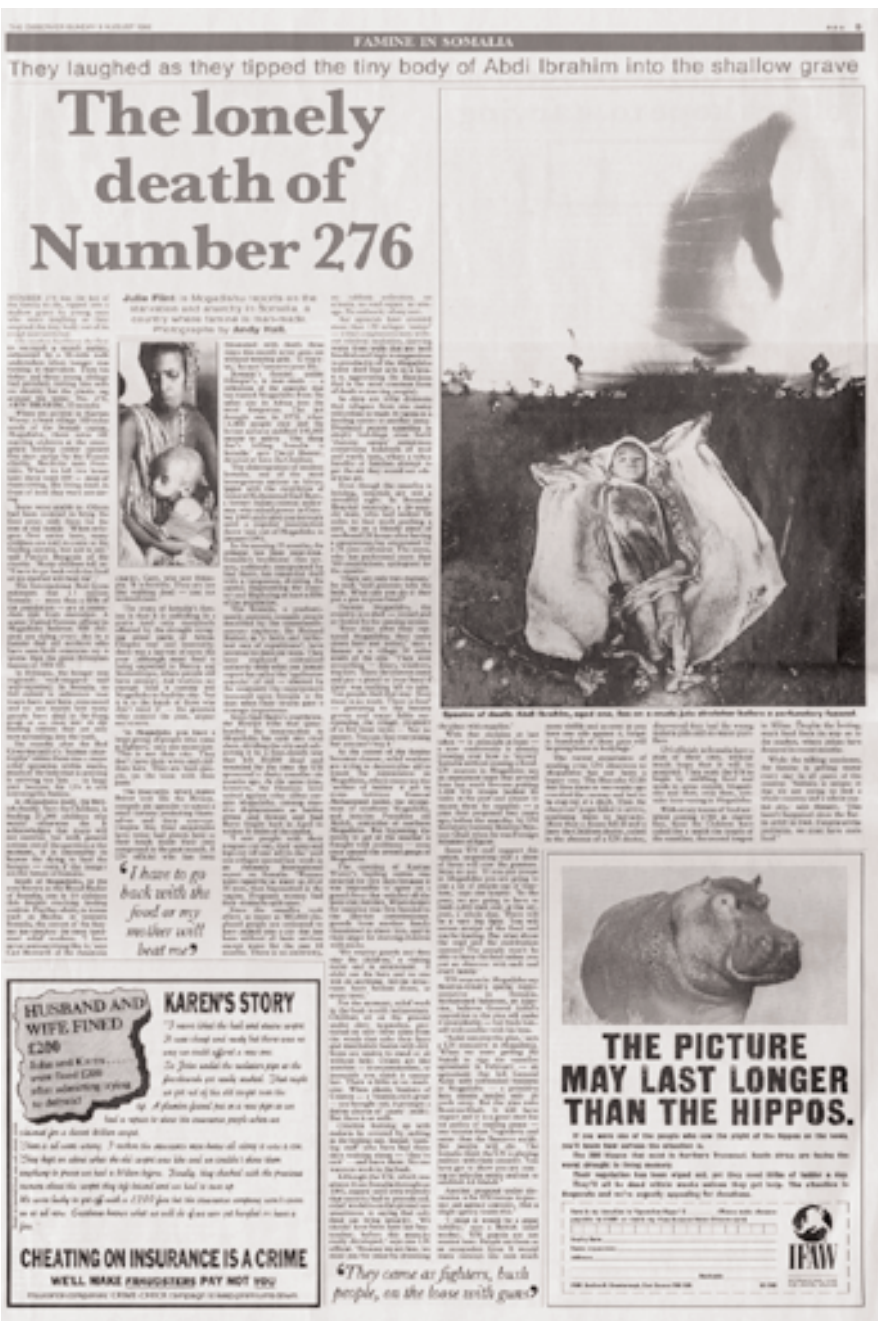

The Observer, August 91992 Photographer: Andy Hall 


\section{geographies of death and}

disaster

"Location, location, location," writes Susan Moeller in Compassion Fatigue. She goes on to cite an American newsroom truism: "One dead fireman in Brooklyn is worth five English bobbies, who are worth 50 Arabs, who are worth 500 Africans." The suggestion here is that audiences care most about those with whom they identify. But then what are the bases of identification? Is it physical proximity that matters, or markers of belonging such as nation and race? Do people who are perceived as distant kin — such as Australians necessarily garner more coverage than Ethiopians or Sudanese, for example? If so, how can other areas command public attention?

The newsroom truism implies that foreign stories are only newsworthy if they involve death and disaster on a massive scale. So how many have to die before a distant event becomes news? The answer to that question is not as clear-cut as it might seem because it depends on a number of factors. Are newspaper editors (who may have very clear ideas of what interests their audiences) equally attuned to all events? How are the events themselves understood - as natural disasters or as complex political emergencies? Is it a slow news day (such as Boxing Day, for example, when the 2004 tsunami struck)? Are economic or political interests perceived to be at stake? Are westerners (tourists, aid workers or soldiers) caught up in the situation or implicated in wrongdoing? Are photographers and reporters available at the scene to provide images and stories? And are innocent victims in ready supply?

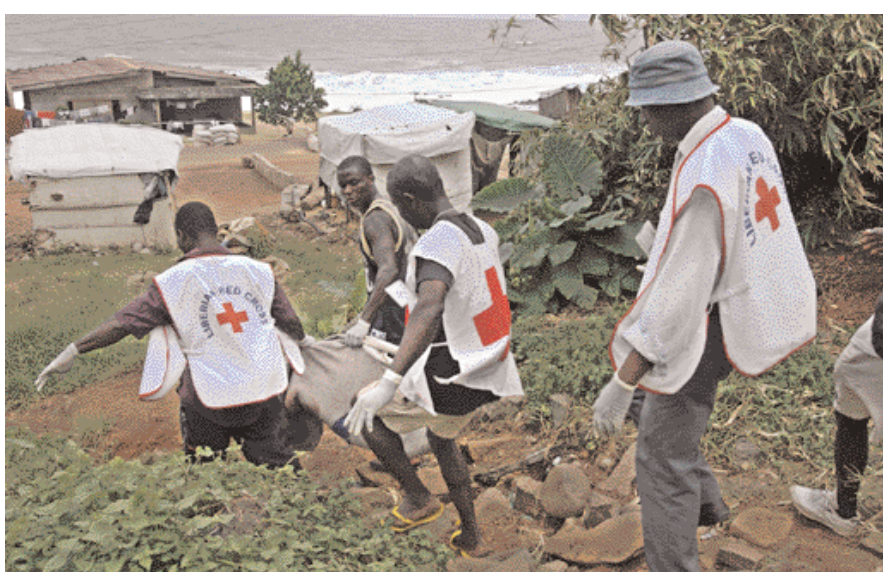

Monrovia, Liberia, 2003

Liberian Red Cross workers collect the body of a young boy killed by a stray mortar. Downtown Monrovia is heavily populated, including tens of thousands of displaced people. All are vulnerable to such mortar attacks. The ongoing conflict in Liberia intensified in March 2003 when rebels opposed to the government of Charles Taylor gained territory across much of the country. In August 2003, Taylor agreed to hand over power to an interim government and went into exile, which led to the signing of a peace agreement.

Martin Adler/Panos Pictures 


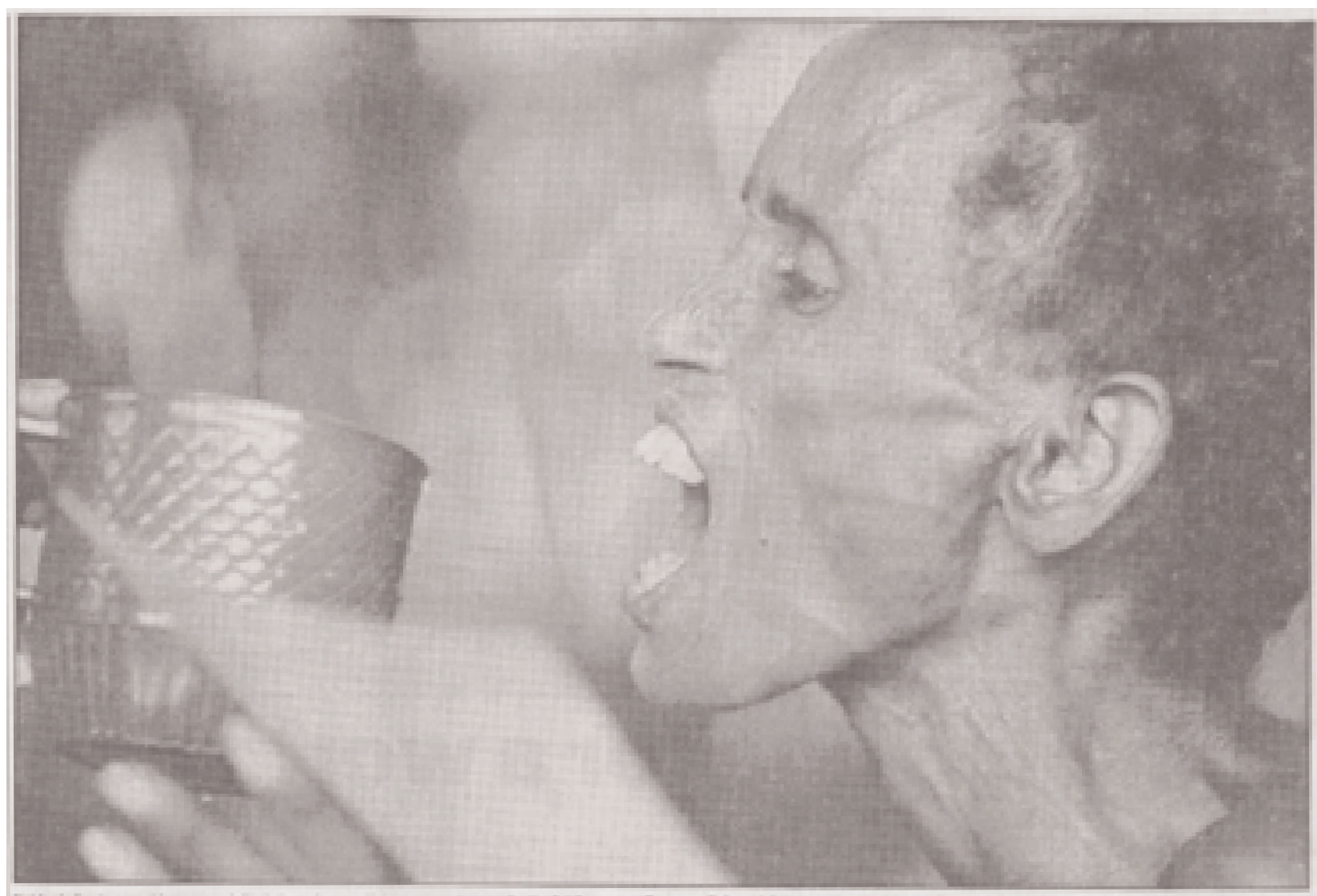

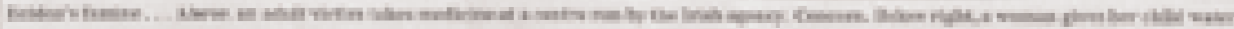

\section{US-led convoy heads for stricken Somali town}

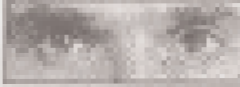 \\ Eycwilnes:}

Mart Hutuna

in Baldo

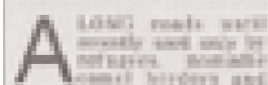

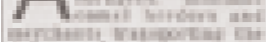

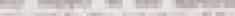

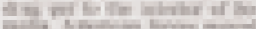

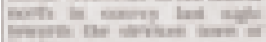
Itate

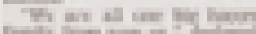

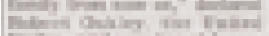

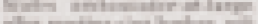

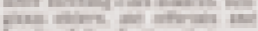

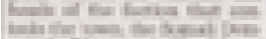

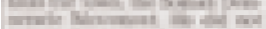

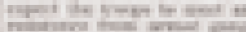

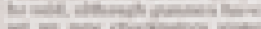

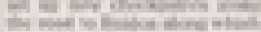

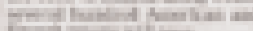

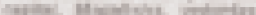

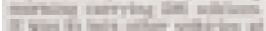

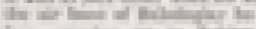

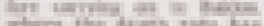

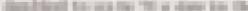
ingming

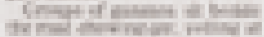

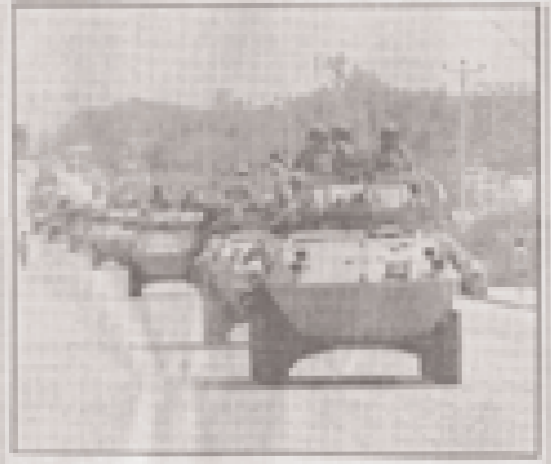

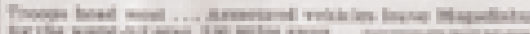

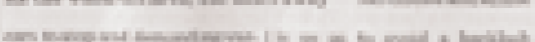

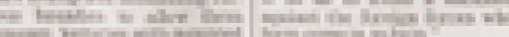

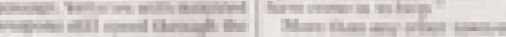

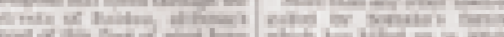

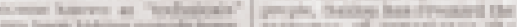

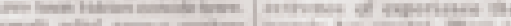

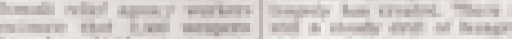

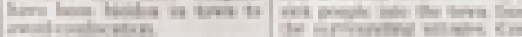

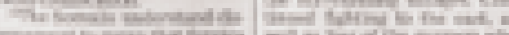

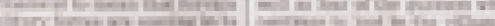

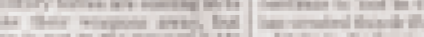

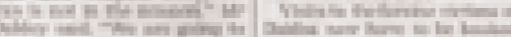

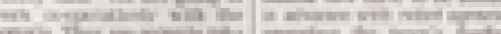

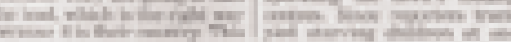
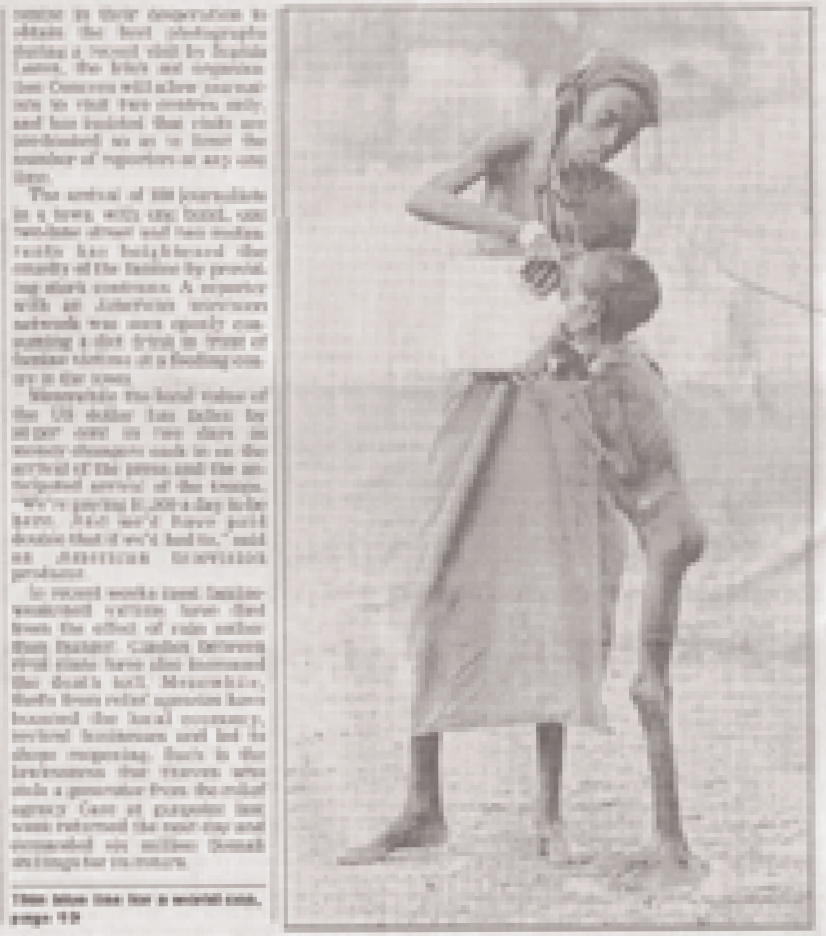


\section{moving images}

Famine images (both in the fundraising campaigns of aid agencies and in newspaper reports) tend to focus on the suffering of women and children. The child sometimes stares into the camera in an accusatory or plaintive way. More often than not, mother and child simply weep. Are such photographs different from the 19th-century images of the poor and destitute produced by European missionaries in Asian and Africa? If not, what does this persistence in form and content tell us? Has "disaster" photography gone beyond its historical connections to the rise of anthropology and the practice of colonialism? Is contemporary photographic practice post-colonial?

"Victim" images appear destined to arouse the emotions of viewers. Children in particular raise strong feelings when they're portrayed as especially vulnerable and weak (at the moment of death, for example, or having been orphaned). Photographs that convey emotional distress may be intended as mere visual representations of suffering, or as signs of societal collapse. They may also consciously elicit the sympathy, pity and compassion of viewers, in the belief that emotional responses attract attention to stories or stimulate charitable giving.

However, the extent to which viewers are actually moved (and if so, how) by emotional images remains debatable. The "compassion fatigue" thesis has it that endless repetition of upsetting images is not a recipe for political understanding, on the one hand, or humanitarian relief on the other, if it induces passivity, despair, helplessness or confusion among viewers and readers. Far from reaching for their wallets to give aid, this thesis suggests that consumers turn away and switch off. A contrasting view claims there is a "CNN effect" where the broadcast or publication of powerful images can force governments to act.

Another thesis was put forward by Sir Bob Geldof in recent television documentaries about Band Aid/Live Aid. Rather than feeling pity and sympathy, Geldof has suggested, the purchasers of the original Band Aid single were moved by anger and outrage. Whereas sympathy may be productive of a charitable impulse, the suggestion is that stronger emotions are required to harness public mobilisation for political justice and change. Is there any evidence, then, that some images have been powerful enough (either on their own or mediated through public opinion) to prompt governments to act or change tack? 


\section{pictures, celebrities and policy}

The BBC's 1984 Amin/Buerk report on the famine in Ethiopia provoked an unprecedented response from the British public, who had already given generously to a national appeal a few months earlier. Aid agencies were deluged overnight with offers of money. Released in November 1984, the Band Aid single Do They Know It's Christmas? was followed in 1985 by the Live Aid concerts in London and Philadelphia - events that stimulated further giving by showing images of dying Ethiopian children to a vast audience. Those same images - from a Canadian Broadcasting Corporation short film, set to the Cars song Drive - were shown again 20 years later to the performers on the Band Aid 20 reprise single as well as used at the press launch of Live 8. Similar images still feature in many charitable appeals and still continue to shock when printed in the papers or screened on the news.

Through its use of celebrities to obtain media attention and raise awareness, Live Aid was unquestionably successful in stimulating charitable giving. But to what extent did Live Aid (or celebrities in general) provide any real depth of political understanding or provoke political change? It's easy to forget that Sir Bob Geldof's personal political crusade (in the wake of the Amin/Buerk report) was ultimately against the Common Agricultural Policy (CAP) of the European Union and not simply against African dictators and insufficient aid. But have efforts such as these produced any noticeable rise in the level of public understanding of the global forces that affect countries in Africa? Even more importantly, have short-term moral imperatives to act to relieve suffering provoked deeper questions about (and changes to) long-term development policy? Has any of this public controversy and debate changed a government's agenda? Continuing calls for the elimination of farm subsidies in the US and Europe, and an end to the CAP for Africa's sake, suggests that enduring political issues remain unresolved. It questions what sorts of images would be required to effectively stimulate structural change.

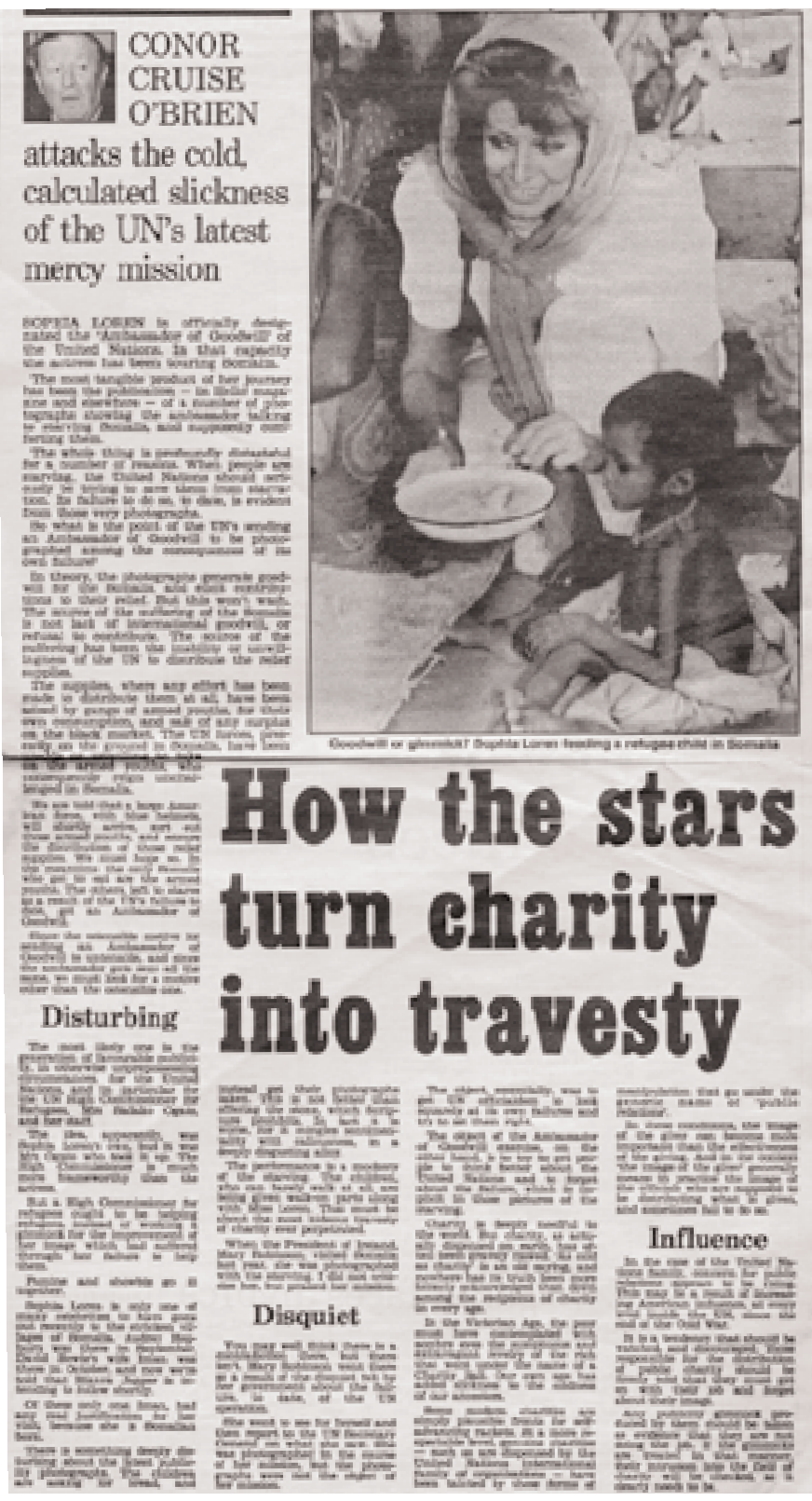




\section{stereotypes, icons and symbols}

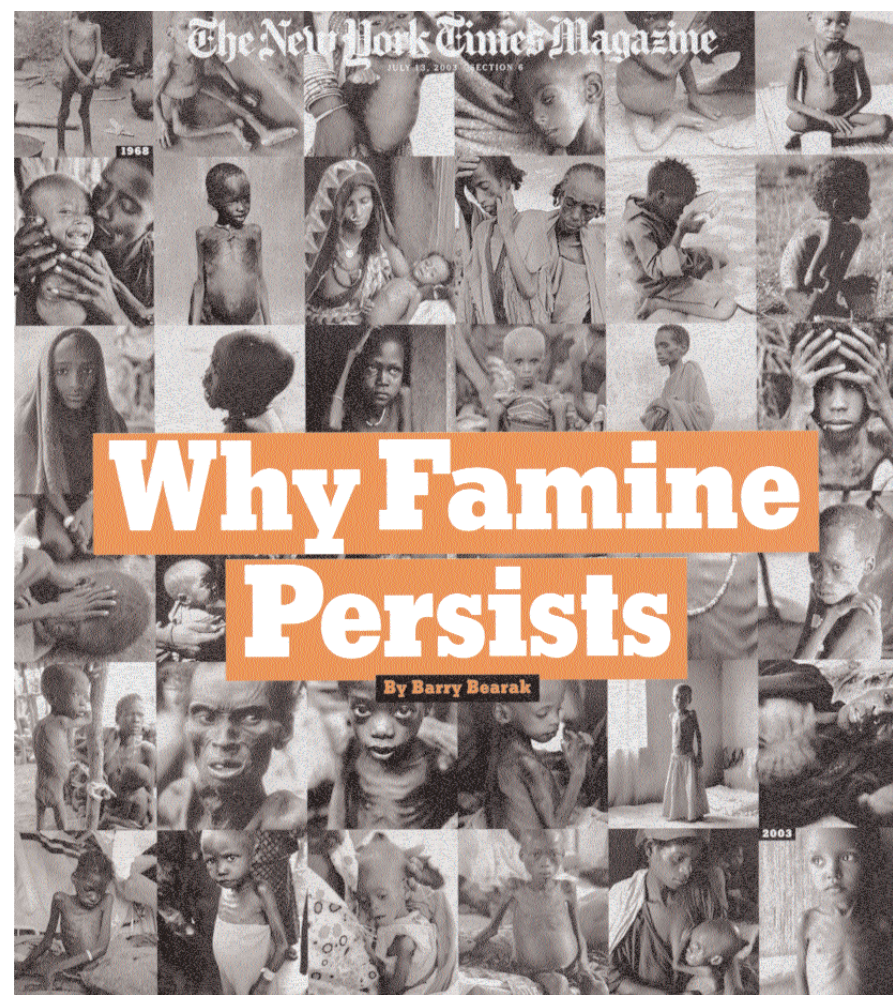

The New York Times, July 132003

No country, let alone continent, is defined by famine. Yet studies of British people suggest that perceptions of African countries remain dominated by negative stereotypes of famine, war and poverty to such an extent that Africa is regarded as a single, impoverished place. While women are often portrayed in ways that conform to gender stereotypes of helplessness, motherhood and dependence on men, images of starving children with bloated bellies and flies around their eyes have become icons of weakness and deprivation. In concert with symbolic images of western aid (such as tents, sacks of grain and aid workers), these add up to distorted views of Africa as one big begging bowl - a place beset by tribal wars, corrupt leaders and uncontrollable natural disasters such as chronic drought. This is what is meant by the Live Aid legacy — the enduring stereotype of the African continent as a "country" neither urban, modern nor efficient, and where everyone is permanently malnourished.

Is there more to the Live Aid legacy, though, than the reproduction of negative stereotypes? On the positive side, Live Aid has been credited with instilling widespread recognition that the fate of the many countries in Africa is our long-term responsibility; that it is a continent where we need to work with indigenous forces promoting major change and future care as opposed to an emergency band aid. Celebrities remain active on the issues of debt, aid and development, and through forums such as the Commission for Africa, political agendas are being promoted in concert with African leaders. As for the general public, Michael Buerk has credited Live Aid with the very opposite of compassion fatigue, suggesting instead that the celebrity activism of the 1980 s convinced ordinary people of their capacity to effect change.

However, the very willingness of ordinary citizens to purchase commodities such as the Band Aid 20 single and Make Poverty History wristbands returns the spotlight to the issue of whether "negative" images are required to move people to act. Aid agencies and the media have been faulted for recycling the same narrow set of images. But they are not the only culprits. The cover of the Band Aid 20 single featured an emaciated African child standing amid polar bears and reindeer, just as the first Band Aid single featured two fly-blown African children surrounded by toys.

To what extent, then, is there a market for images that might surprise and delight? Why do we not regularly see non-traditional images (of cultural, political and sporting events, for example) that disrupt stereotypes? Are war, famine and poverty the only newsworthy items? Even if the answer to that is an unqualified yes, are the most powerful images necessarily those that reinforce cultural cliches as opposed to the more complex ones that attempt to convey knowledge, understanding, context and explanation? And are indigenous photographers with local knowledge any more likely than ones to produce challenging images? 


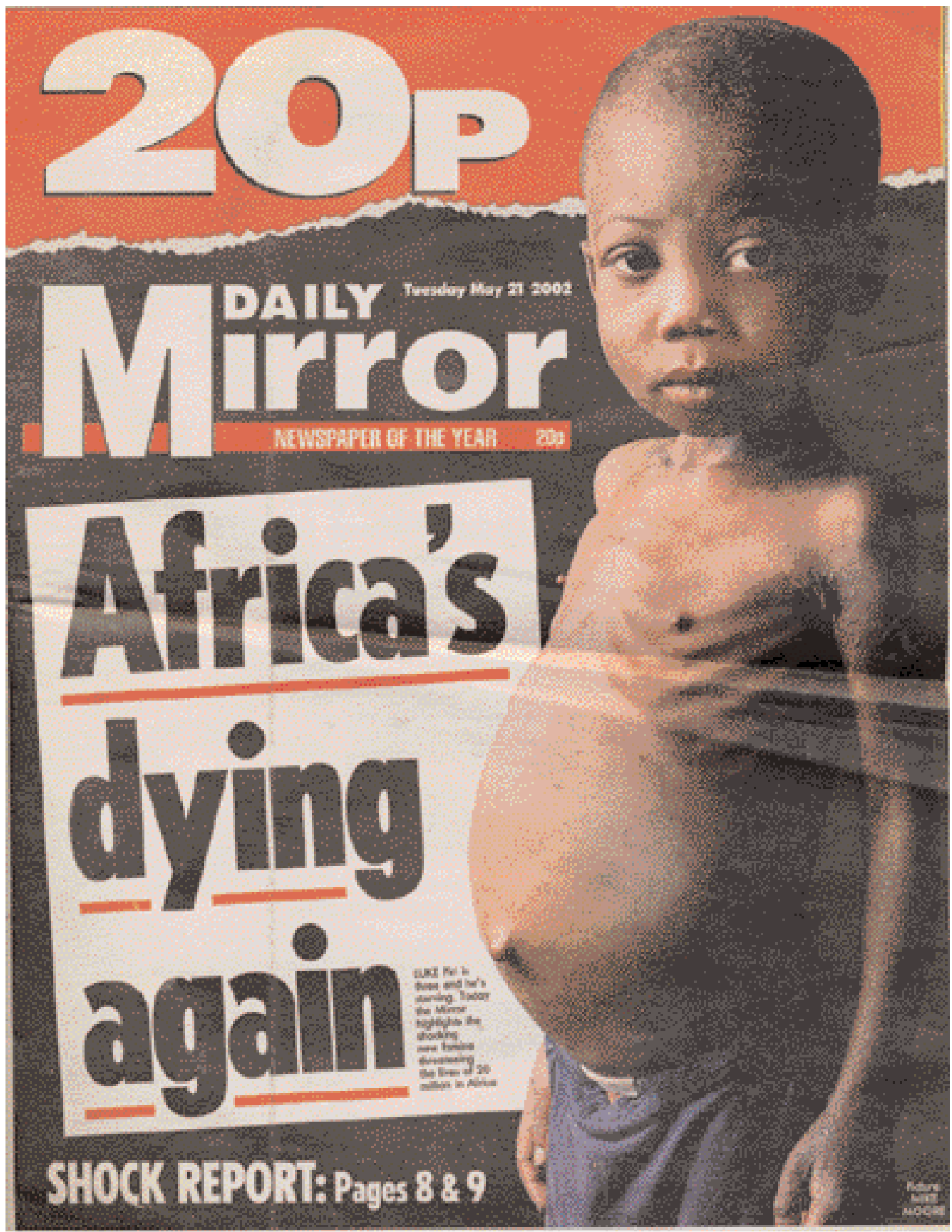

Daily Mirror, May 212002 Photographer: Mike Moore Courtesy of Mirror Group Newspapers 


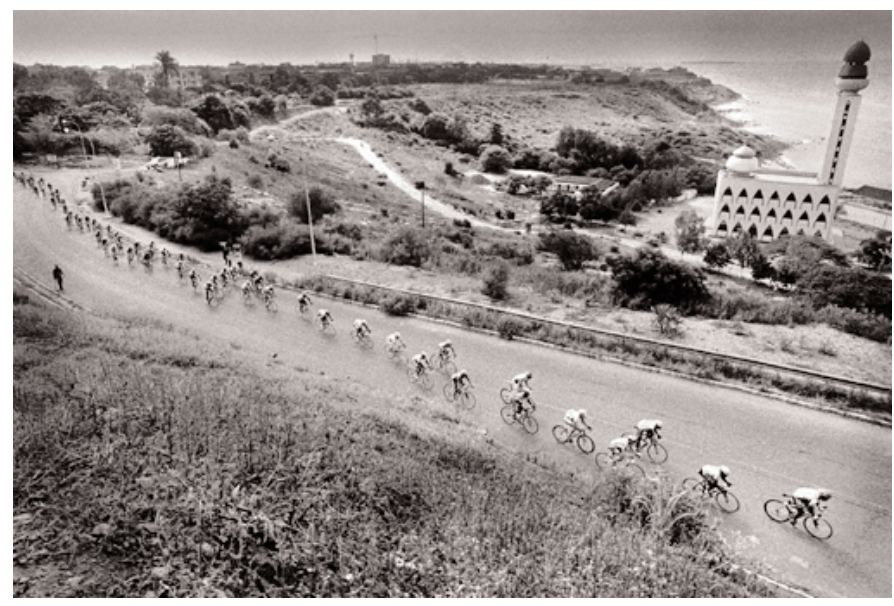

Dakar, Senegal, 2002

The pack passes a mosque along the coastline on the outskirts of Dakar. The Tour du Senegal, a two-week cycle race held in average temperatures of $40 \mathrm{C}$, traverses the country with a total distance of $1168 \mathrm{~km}$.

Chris Keulen/Panos Pictures

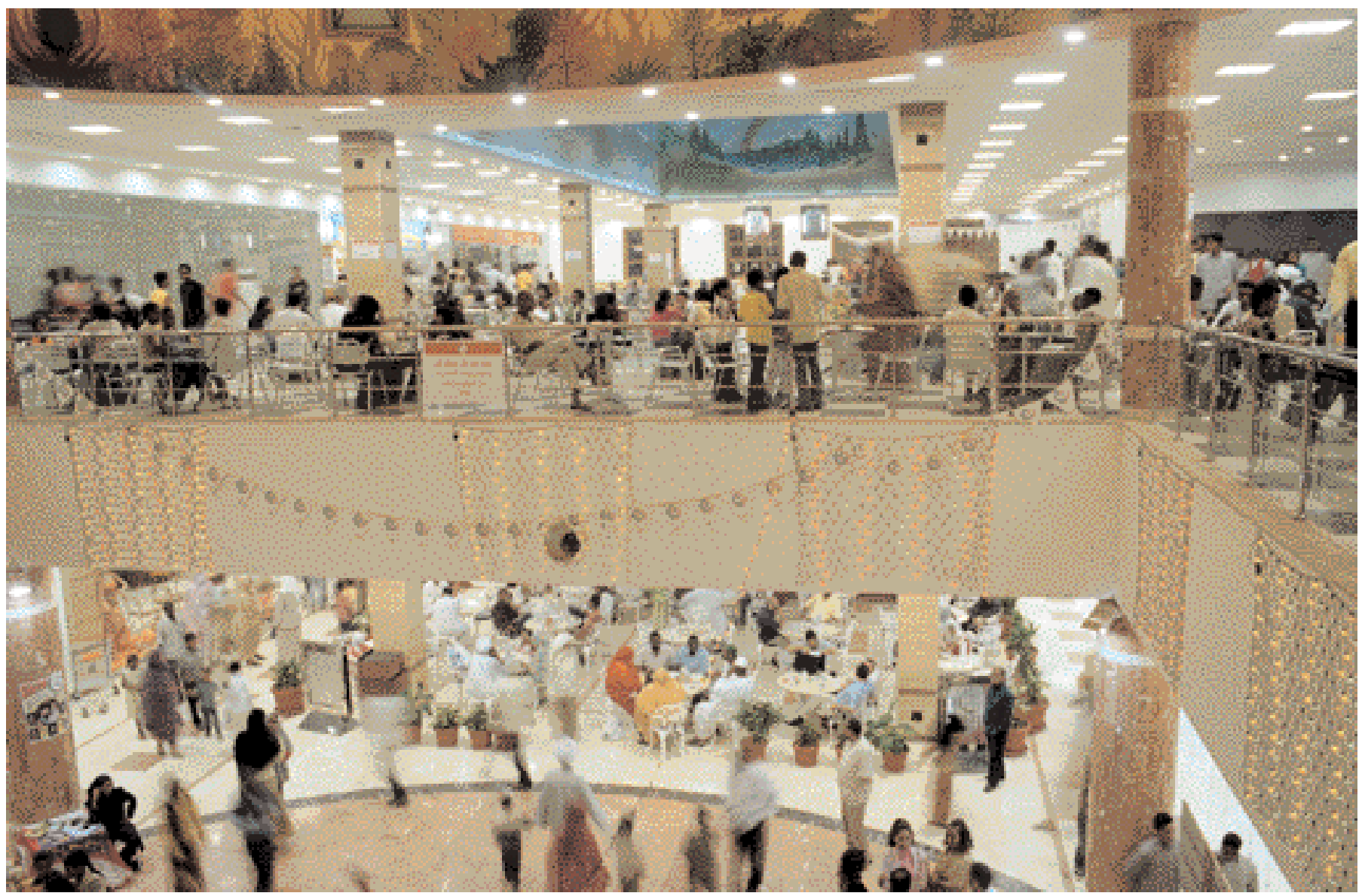

Khartoum, Sudan, 2004

Shopping mall

Petterik Wiggers/Panos Pictures 


\section{visual memory}

Which technology dominates the news media: still or moving images? Biafra in the late 1960s was perhaps the last conflict where photojournalists scooped television crews for pictures of the crisis. But if moving images are now dominant and ubiquitous, does that mean still images have lost their significance? Almost certainly not, though the way in which they are regarded as significant could have changed.

Photojournalism and documentary photography remain a culturally significant source of knowledge. As much as people are rightly sceptical about the inherent objectivity of the image, photographs retain a gravitas that the everyday and all-consuming stream of television can find hard to match. Will still photography gain a renewed importance as television increasingly neglects the world beyond our tabloid concerns? Is it the case that we remember events in terms of single, still photographs rather than streams of video?

Those iconic images that we can readily recall often invoke other pictures. They might look like paintings, or recall other historical photographs, or invoke the conventions of Christian iconography - mother and child in a Madonna-like pose, or aid workers adopting the form of a healing saviour. Are such images just reflections of what is in front of the lens? Or has the photographer directly or indirectly relied on established artistic traditions to produce a powerful picture?

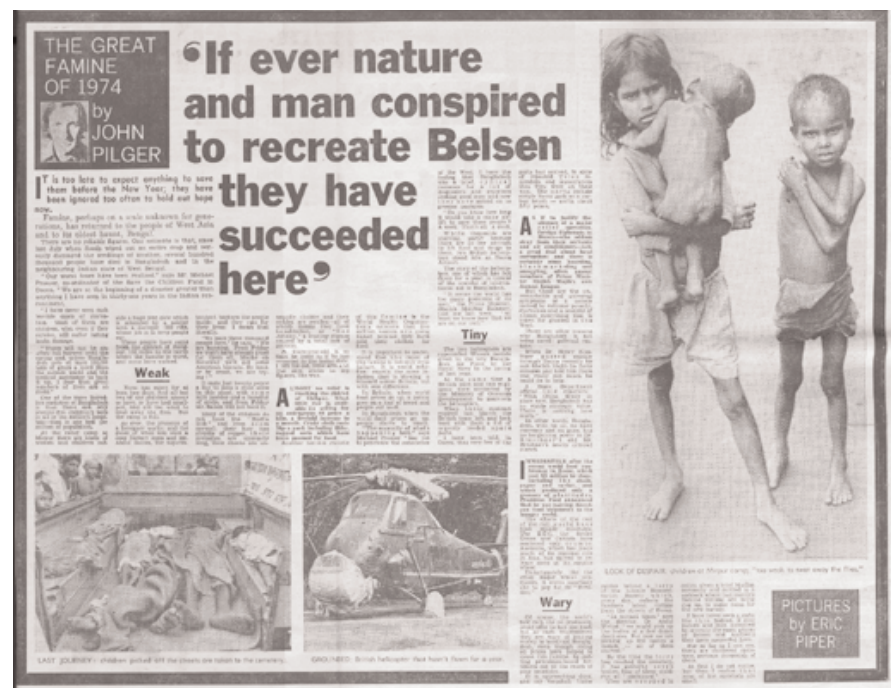

Daily Mirror, December 171974 Photographer: Eric Piper courtesy of Mirror Group Newspapers 


\section{time and place}

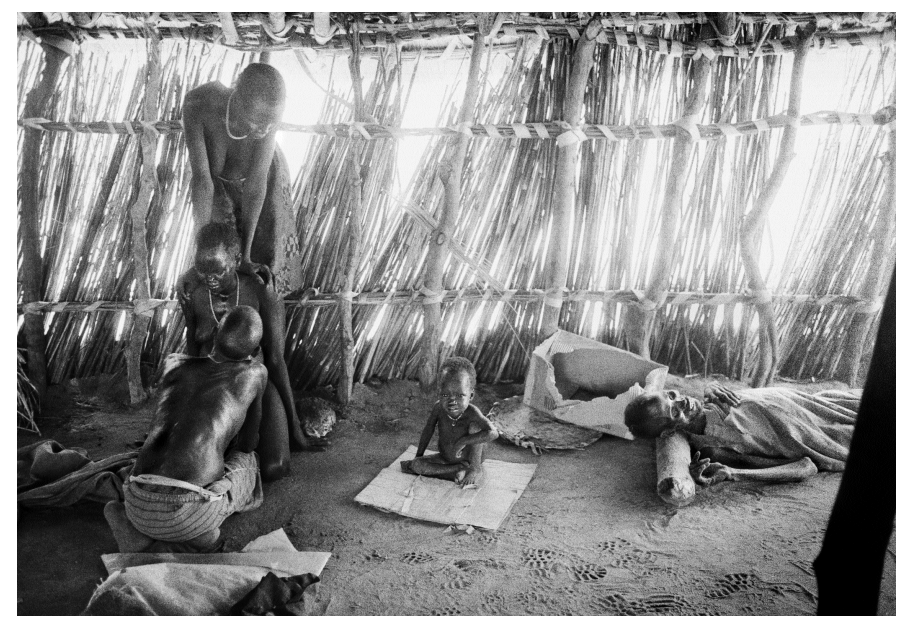

Sudan, 1998 Photographer: Tom Stoddart

New technologies have brought new opportunities.

Photographers shooting in Los Angeles, Liverpool or Lima upload their images to global picture desks in places such as Singapore, where they are edited and transmitted digitally to the desktops of picture editors around the world. The whole process should only take a few minutes - any longer and the competition will have the edge. Immediacy is the key. But does this mean that the independent photographer's eye is being replaced by the need for impact, speed and the understanding of a global audience? Does this force the use of simplified familiar compositions?

Tight competition means tight budgets. It is rare to send photographers for months to document an ongoing crisis particularly in a place unfamiliar to those who control the commissions. Can a photographer be expected to reflect on the complexity of an issue they have only been introduced to the day before - or do they just invoke the stock concerns of those who dispatched them? What is the difference, if any,

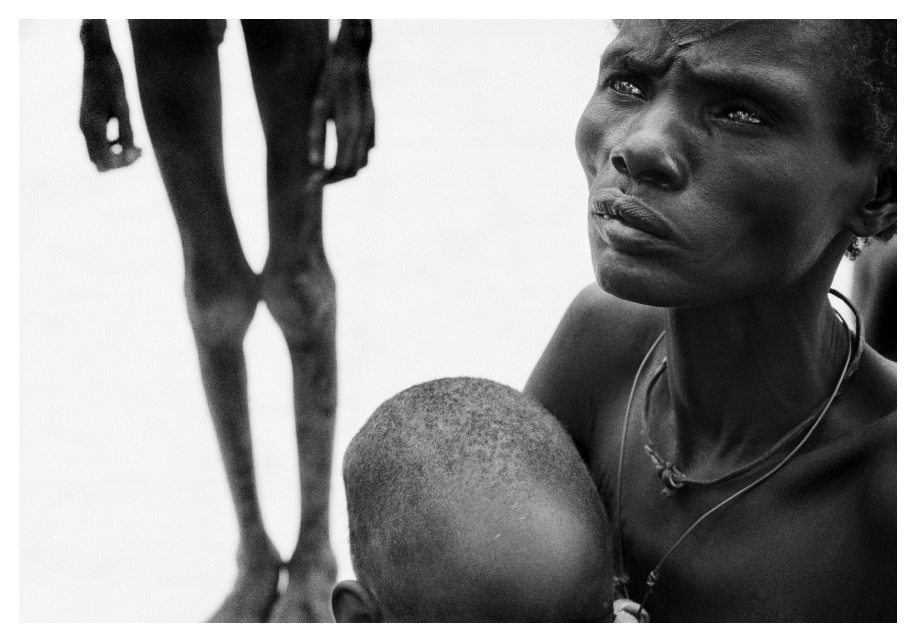

between images produced by rising numbers of local photographers in Asia and Africa and those sent in from the global north? There is a move towards training and using indigenous image makers, but will they be allowed an indigenous voice or will the predominantly northern market demand the northern perspective? And what happens to the images of places least requested, when loaded into databases that search by popularity?

As lifestyle issues and celebrity features devour the pages of the weekend supplements, the serious photo essay is often compressed to a single image. Can a photographer be expected to give an understanding to his/her audience with just one picture? If this is the future, what can be learned from advertisers who have mastered the art of triggering an emotional response through visual metaphors? 


\section{responsibility}

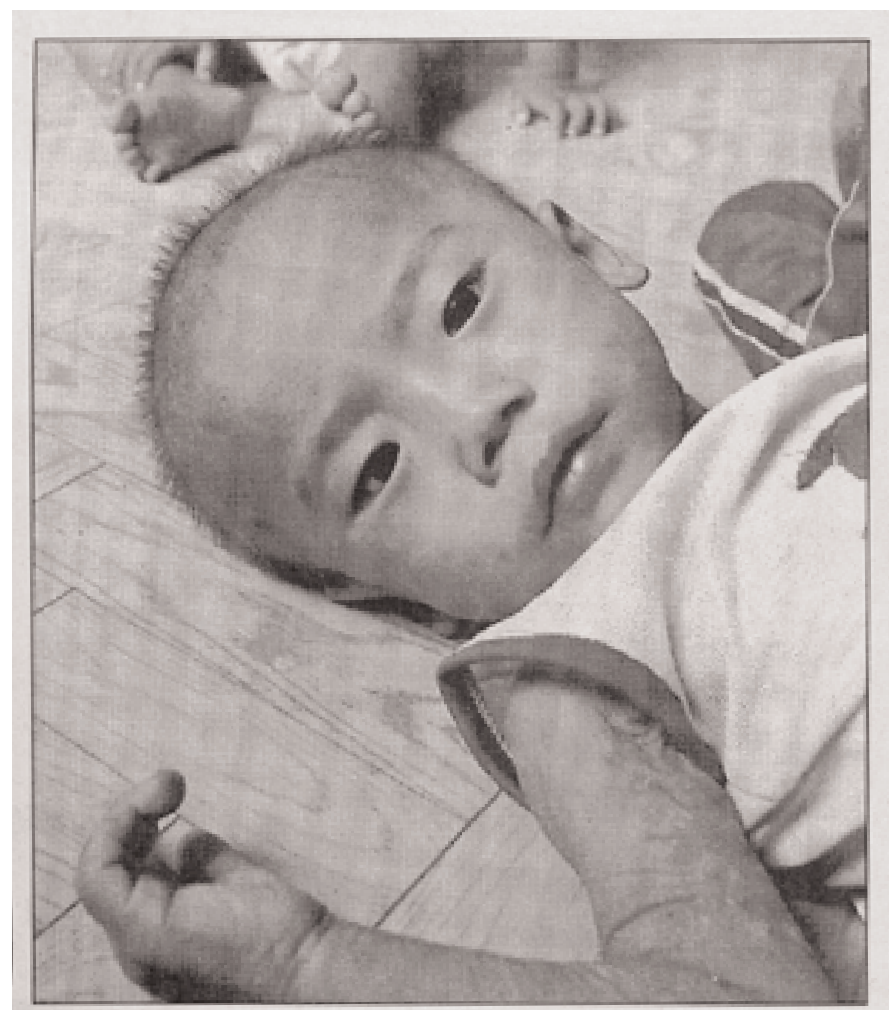

\section{A nation's hunger in a child's face}

This is what hunger does. Kim Su Sim is a undernourished child in a North Korean hospital. He had been staring into space when he suddenly toppled over and lay motionless on the floor, still with the same listless gaze of hunger.

The maize crop has failed and the drought is rotting the rice in the fields,' said Marie Staunton, deputy director of Unicef in Britain, on her return from North Korea last Friday.

A cold winter will soon hit the country and $800,000 \mathrm{mal}$. nourished children will be at risk, and things will be worse than Ethiopia or Somalia.'
The Guardian, August 181997 Photographer unknown
Where does this leave photography in the process of responding to humanitarian disaster? Are photographers simply image workers, or do they have wider responsibilities? Faced with suffering, do they take the picture or dole out aid? Kevin Carter, who shot the 1993 Pulitzer Prize-winning image of the vulture and child in Sudan, was repeatedly criticised by newspaper readers for not assisting the child directly. Should there be a moral code which guides photographers on when to act or is their responsibility best exercised by taking the pictures?

Probably the world's worst famine occurred in China between 1959 and 1961, where an estimated 40 million people died. Chinese photographers were present but due to a combination of local culture, political power and lack of resources any pictures they did take were not publicly used. Text reports were common at the time with much debate in the British newspapers over how to deal with the issue. However with no pictures, there was no proof and no action. Would there have been the same massive response to the 1984 Ethiopian famine if Michael Buerk had produced a report without Mohamed Amin's images?

What about the opinions of the people who appear in disaster photographs? The photographer is often criticised for not considering the dignity of their subjects - for preying on people at the lowest moment of their lives, too weak to muster a response or run from the gaze of the lens. Or could it be that this is all victims of atrocity and disaster can do? Be photographed. Is this in itself a strategy for survival, offering their image in return for aid provided by an organisation that needs those pictures to raise the funds to buy that aid? 


\section{Sudan Is Described as Trying to Placate the West}

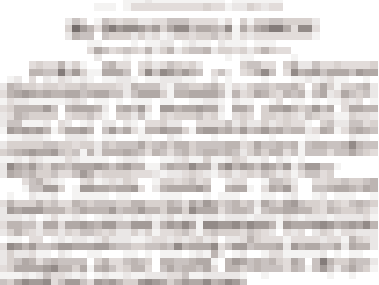
217

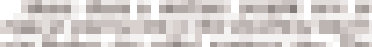

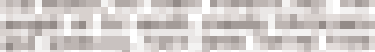

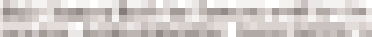

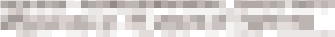
-

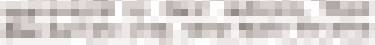

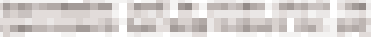

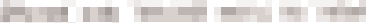

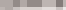

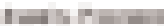

ctrix =

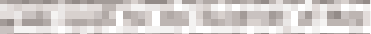

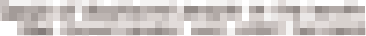
-

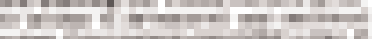

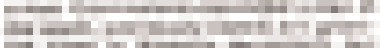

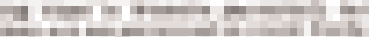

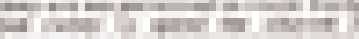

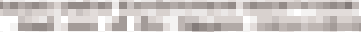

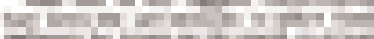

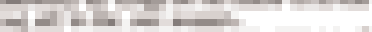
군 Che - 1 mat -

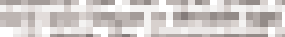

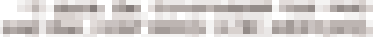

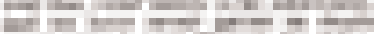

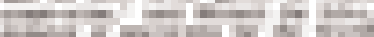
-

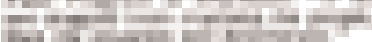

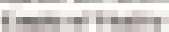

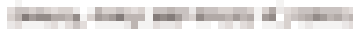

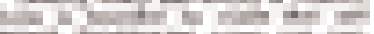

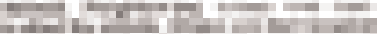

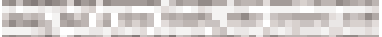

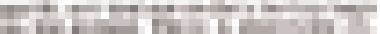

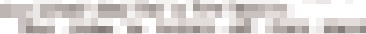
는

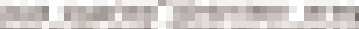
-

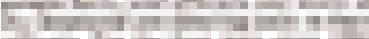

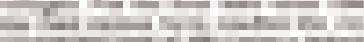
2

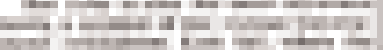

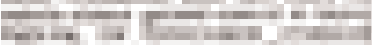

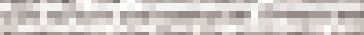

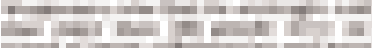

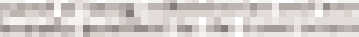

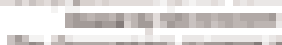

cherar -

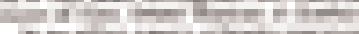
trima

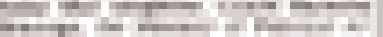

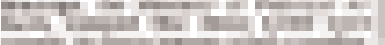

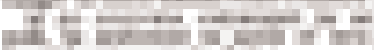
Chr

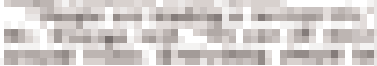

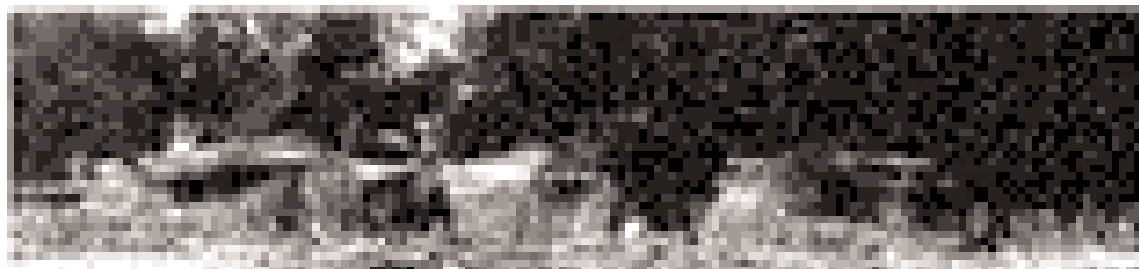

H

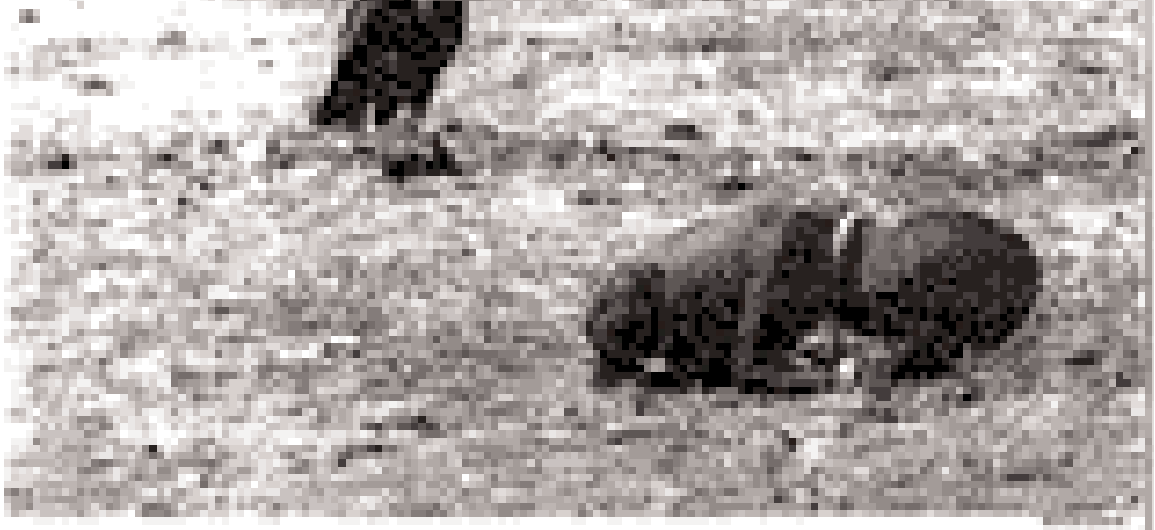

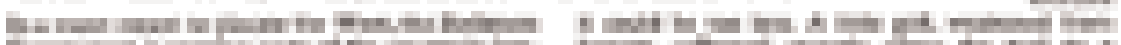

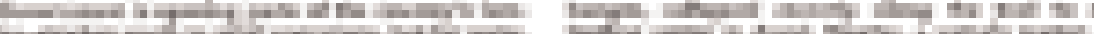

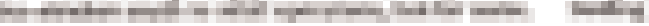

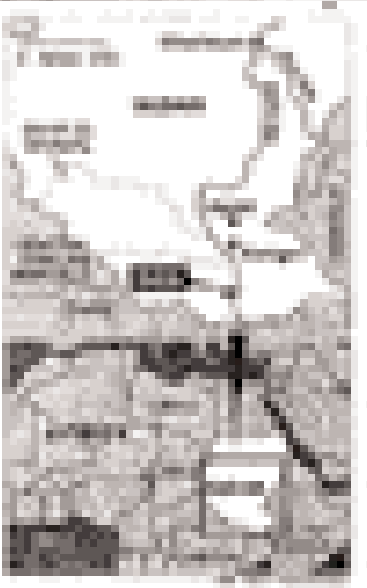

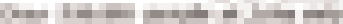

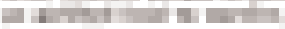

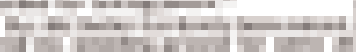

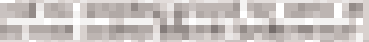
돈

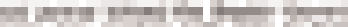

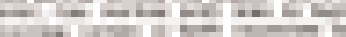

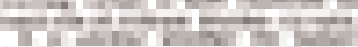

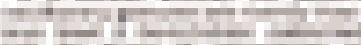
An

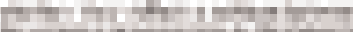

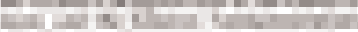

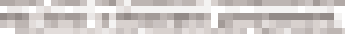

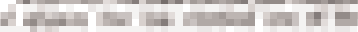

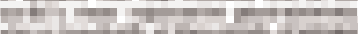

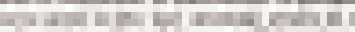

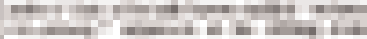

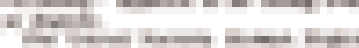

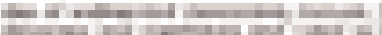

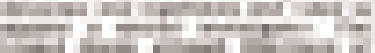

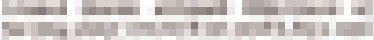

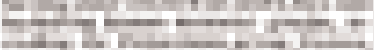

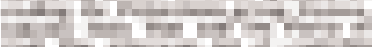

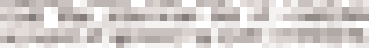

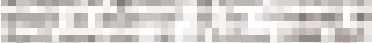

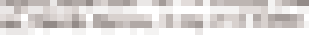

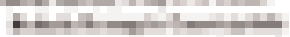

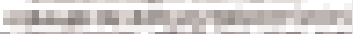
(4)

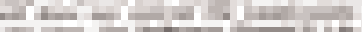

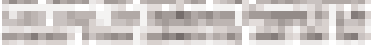

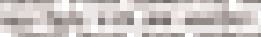

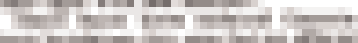

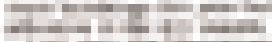

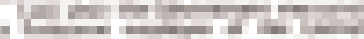

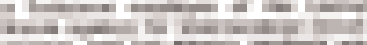

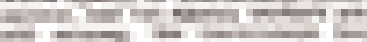

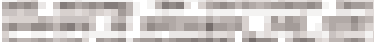
bin-

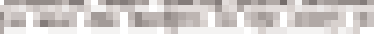

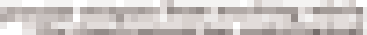
1,

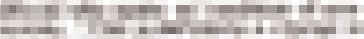
triming I

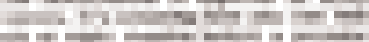

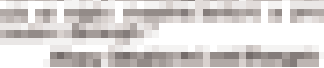

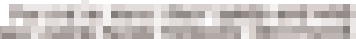

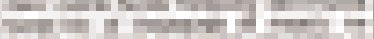

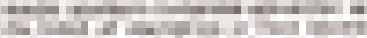

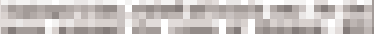

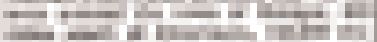
하으.

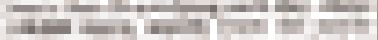

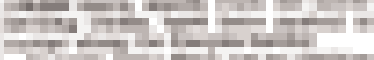

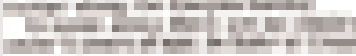

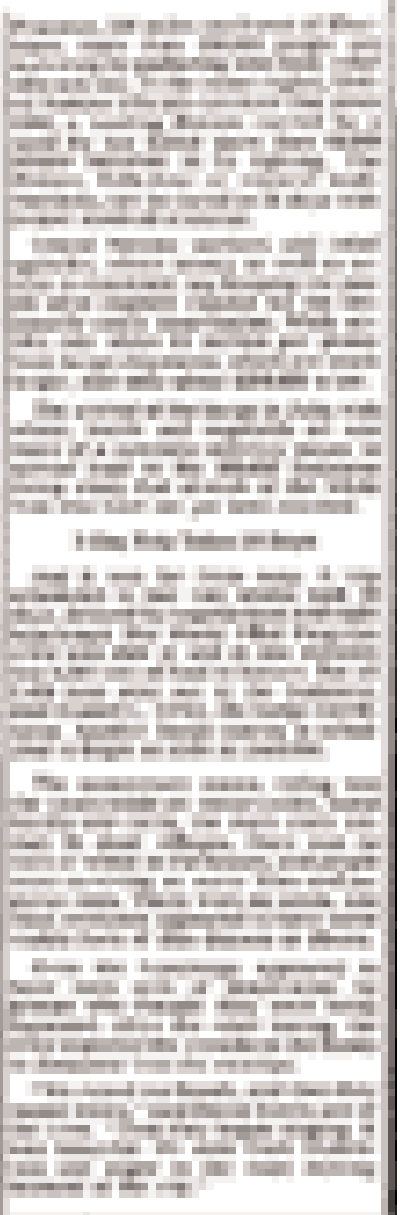




\section{References}

Bob Smith with Salim Amin, The Man Who Moved the World: The Life and Work of Mohamed Amin (Nairobi: Camerapix Publishers International, 1998).

Susan D Moeller, Compassion Fatigue: How the Media Sell Disease, Famine, War and Death (New York and London: Routledge, 1999).

Food and Agriculture Organisation, Images of Africa, available at www.imaging-famine.org/resources

This text was written by David Campbell, DJ Clark and Kate Manzo, with research assistance from Caitlin Patrick, July 2005.

\section{Curators}

David Campbell is professor of cultural and political geography at Durham University, and associate director of the Durham Centre for Advanced Photography Studies. His books include National Deconstruction: Violence, Identity and Justice in Bosnia (Minneapolis: University of Minnesota Press, 1998), and Moral Spaces: Rethinking Ethics and World Politics, edited with Michael J Shapiro (Minneapolis: University of Minnesota Press, 1999). National Deconstruction was named International Forum Bosnia's Book of the Year 1999, and was translated and published in Sarajevo in 2003. Campbell has published a series of essays on the politics of photography, including "Salgado and the Sahel: Documentary Photography and the Imaging of Famine" in Rituals of Mediation: International Politics and Social Meaning, edited by Francois Debrix and Cindy Weber (Minneapolis: University of Minnesota Press, 2003), and "Horrific Blindness: Images of Death in Contemporary Media", Journal of Cultural Research 8 (2004). He is currently working on a book project entitled Humanitarian Visions, which explores the visual culture (especially the pictorial representation of war, famine and atrocity) of international politics and political geography.

DJ Clark is lecturer and programme leader on the MA photography at the University of Bolton, a photojournalist represented by Panos Pictures, and is completing a $\mathrm{PhD}$ in the geography department at Durham University. In 2003 he was awarded a Winston Churchill travelling fellowship for research in Bangladesh and Ethiopia which was published in "The Production of a Contemporary Famine Image", Journal of International Development, 16 (2004). He has also authored a forthcoming article "China, Photography and Famine".

Kate Manzo is lecturer in international development in the school of geography, politics and sociology at the University of Newcastle. She has published widely on race, nationalism and development, including Creating Boundaries: The Politics of Race and Nation (Boulder: Lynne Rienner, 1996), "Africa in the Rise of Rights-based Development," Geoforum, 34 (2003), and "Exploiting West Africa's Children: Trafficking, Slavery and Uneven Development," Area (forthcoming 2006). She is currently working on a project called Baby Face: Images of Suffering in Social Justice Campaigns, which asks whether the use of stereotypical imagery of Africa can ever be justified.

\section{Research associate}

Caitlin Patrick holds an MA in political science from York University in Toronto, and is working on a PhD in the geography department at Durham University, having been awarded a Social Sciences and Humanities Research Council of Canada doctoral fellowship. Her dissertation research is concerned with the print and television media coverage of the 1992-93 US/UN intervention in Somalia, and investigates whether this coverage influenced policymakers' and public understanding of the intervention. Her broad research interests include political theory, visual culture and global geopolitics, and gender issues in global politics.

\section{Consultant}

Paul Lowe is a photojournalist with over 15 years' experience working in war zones such as Bosnia and Chechnya as well as covering famines in Somalia and Sudan. Represented by Panos Pictures, his work has been widely published in major national and international publications, as well as in his book Bosnians (London: Saqi Books, 2005). Lowe is programme leader on the MA in photojournalism and documentary photography, London College of Communication, University of the Arts, London, where he is also undertaking $\mathrm{PhD}$ research on the aesthetics and ethics of contemporary photographic practice.

\section{Acknowledgments}

The curators would like to express their thanks to the following individuals who kindly agreed to be interviewed for this project (but who bear no responsibility for the views expressed):

Shahidul Alam, Drik

Pep Bonet, photographer, Panos

Pictures

Damian Conlin, Cafod

Arko Datta, photographer, Reuters

Lucy Davies, Oxfam

Peter Davis, Oxfam

Ayperi Karabuda Ecer, Reuters Adrian Evans, Panos Pictures Jan Grarup, photographer, Politiken Christiane Gehner, Der Spiegel Mike Goldwater, photographer, London Joseph Harker, The Guardian Grace Lau, London College of Communication

Stephen Mayes, Art + Commerce

Tom Stoddart, photographer, London 
Roger Tooth, The Guardian

Roland Unwin, Cafod

Nikki van der Gaag, Oxford

Laurence Watts, Action Aid

Val Williams, London College of

Communication

Thanks to Joanna Jarvis and Xu Shu Min for the graphic design of the boards and website.

The staff of the design and imaging unit in the department of geography at

Durham University provided much timely assistance with the scanning and production of images.

Special thanks to the staff of Panos Pictures for their on going support, especially the director, Adrian Evans, and David Arnott, Michael Regnier and Teresa Wolowiec.

For their backing, encouragement and effort in making the exhibition possible, we would also like to thank the staff of the Newsroom. 


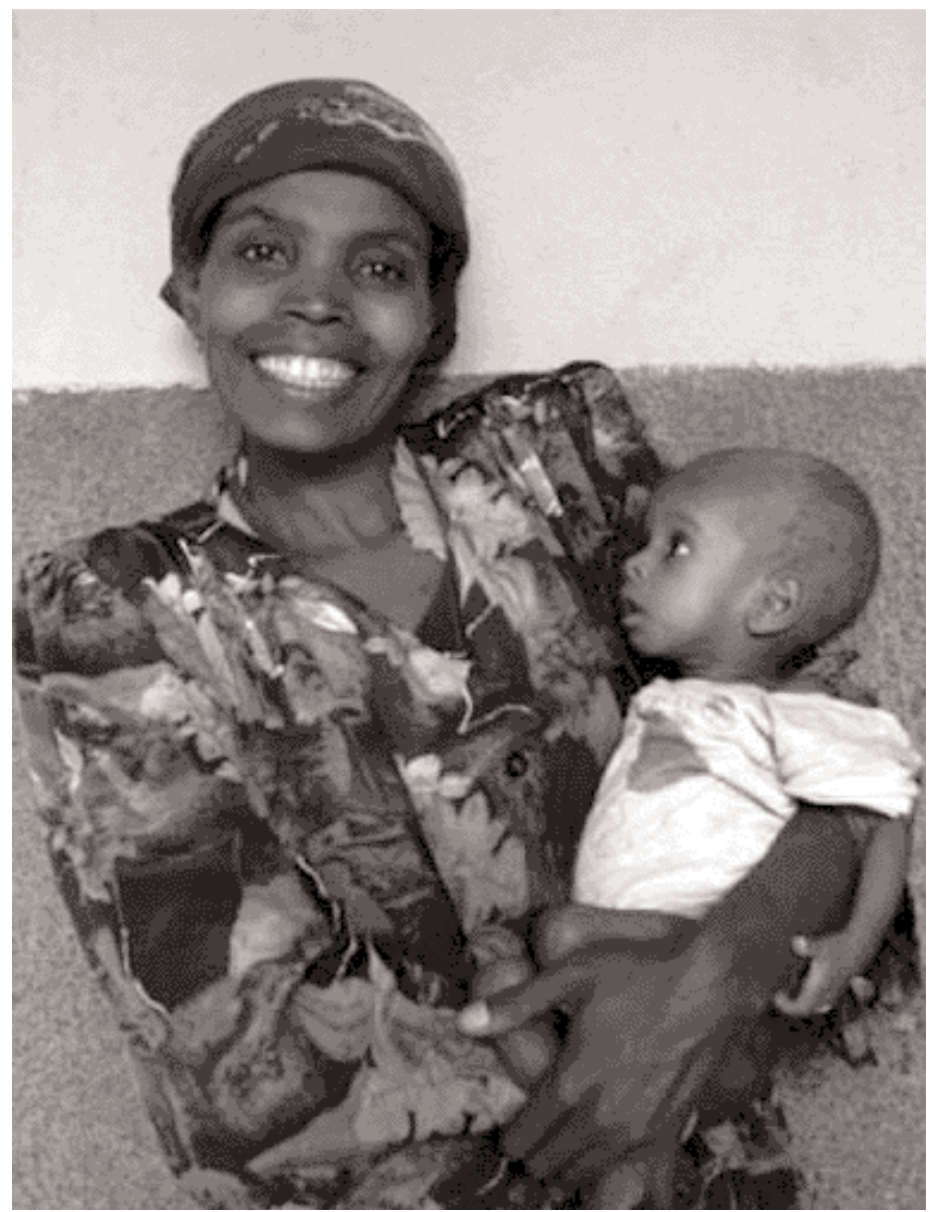

Mekanic Philipos, Ethiopia, May 2003 Photographer: DJ

\section{Imaging Famine}

An exhibition held at the Newsroom, the

Guardian and the Observer archive and visitor

centre, fromAugust 5 to September 92005.

For further information call 020-7886 9898

visit guardian.co.uk/newsroom

oremail newsroom@guardian.co.uk

\section{www.imaging-famine.org}

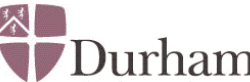 University}

Durham Centre for Advanced Photography Studies
象

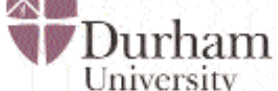

University

Departuent of Geography

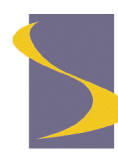

Bolton
UNIVERSITY OF NEWCASTLE UPON TYNE

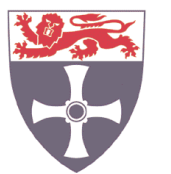

London College of

Communication 